\title{
Thick Filament
}

National Cancer Institute

\section{Source}

National Cancer Institute. Thick Filament. NCI Thesaurus. Code C33762.

A myofilament composed of myosin. 